\title{
Eosinofil gastroenteritt
}

\author{
Sammendrag \\ Bakgrunn. Eosinofil gastroenteritt er \\ en sykdom som gir uspesifikke sympto- \\ mer i form av magesmerter, kvalme og \\ diaré. Det er begrenset kunnskap om \\ tilstanden og vi presenterer en oversikt \\ som kan være til nytte ved diagnostikk \\ og behandling.
}

Materiale og metode. Artikkelen er basert på egne erfaringer med pasienter med eosinofil gastroenteritt, og tilstanden er illustrert med en kasuistikk fra egen avdeling. Vi har i tillegg gjort søk i PubMed på engelskspråklige artikler innen emnet.

Resultater. Eosinofil gastroenteritt er en sjelden, kronisk betennelsestilstand i mage-tarm-kanalen som hovedsakelig rammer ventrikkel og øvre del av tynntarm. Tilstanden er hyppigst hos unge til middelaldrende voksne, med en overvekt av menn. Etiologi og patogenese er ukjent. De vanligste symptomene er magesmerter og diaré. Diagnosen kan være vanskelig å stille hvis man ikke er oppmerksom på tilstanden og baserer seg på tilstedeværelse av symptomer fra fordøyelsessystemet, selektiv eosinofil infiltrasjon i magetarm-kanalen og fravær av andre årsaker til eosinofili. Sykdommen behandles symptomatisk med kortikosteroider i varierende dosering, og langtidsprognosen synes god.

Fortolkning. Den kliniske presentasjonen av eosinofil gastroenteritt er svært variabel og tilstanden er sannsynligvis underdiagnostisert. Mange pasienter har normale eosinofile granulocytter i blod og normale funn ved endoskopi. Korrekt diagnose er derfor avhengig av at man er oppmerksom på tilstanden.
Gunnar Qvigstad

gunnarq@ntnu.no

Avdeling for fordøyelses- og leversykdommer Medisinsk klinikk

Trond Viset

Avdeling for patologi og medisinsk genetikk Laboratoriemedisinsk klinikk

Reidun Fougner

Klinikk for bildediagnostikk

St. Olavs hospital

7006 Trondheim

Eosinofil gastroenteritt er en sjelden tilstand som typisk gir uspesifikke symptomer i form av magesmerter, kvalme og diaré. Sykdommen ble først beskrevet av Kaijser i 1937 (1) og kjennetegnes av inflammasjon med eosinofile granulocytter i tarmveggen i mage-tarm-kanalen. Årsaken er ukjent, og diagnosen kan være vanskelig å stille da tilstanden er lite kjent og symptomene kan være vage. Differensialdiagnostisk finnes det en rekke tilstander som enten gir liknende symptomer eller eosinofili. Vanlige tilstander som gastroøsofageal refluks, inflammatorisk tarmsykdom, cøliaki og parasittinfeksjoner kan sekundært gi eosinofil infiltrasjon i slimhinnene. Primær eosinofil inflammasjon i mage-tarm-kanalen er mest vanlig i oesophagus, såkalt eosinofil øsofagitt, og gir typisk dysfagi hos unge, ellers friske individer. Vi vil i denne oversikten sette søkelyset på eosinofil gastroenteritt som kan gi mer dramatiske symptomer og føre til innleggelse i sykehus.

\section{Materiale og metode}

Oversikten er basert på egne erfaringer med fire pasienter med eosinofil gastroenteritt som vi har fulgt over tid ( $>1$ år), illustrert med en kasuistikk. Vi har i tillegg gjort søk i PubMed på engelskspråklige artikler med søkeordene «eosinophilic gastroenteritis» i tittel, noe som ga 279 treff. Det var kun en ikkerandomisert prospektiv klinisk studie, og for øvrig var det kasuistikker, små retrospektive studier og oversiktsartikler. Totalt er det kun rapportert om noen få hundre pasienter med tilstanden. Basert på egen erfaring innen feltet gjorde vi et skjønnsmessig utvalg av artikler som grunnlag for denne artikkelen.

Kasuistikk

En 39 år gammel mann ble innlagt etter at han i flere uker hadde vært plaget med sure oppstøt, oppblåst mage og nedsatt matlyst.
Mat og/eller drikke utløste kvalme og oppkast etter 2-3 timer. Han trodde selv han hadde gått ned i vekt på grunn av anoreksi men hadde ikke veid seg. Han kom opprinnelig til en poliklinisk gastroskopi hvor man fant ventrikkelretensjon og dårlig oversikt, men slimhinnene $i$ antrum og duodenum virket betente. Det ble tatt blodprøver som viste leukocytter 16,8, CRP 30, LD 246, eosinofile granulocytter 5190 (31\% av totalt antall leukocytter), ellers helt normal blodprøvestatus. På grunn av kliniske og endoskopiske funn ble han innlagt dagen etter til videre utredning. Ved innkomst var han afebril og det var upåfallende forhold ved klinisk undersøkelse. Han hadde ni år før det aktuelle en episode med akutt pankreatitt uten kjent etiologi. To år før aktuelle innleggelse hadde han en periode med tilsvarende symptomer, men disse gikk over av seg selv $i$ løpet av et par måneder.

$\mathrm{Ny}$ gastroskopi etter innkomst viste noe ødematøse slimhinner i duodenum som gjorde det noe vanskelig å intubere pars descendens duodeni med endoskopet, ellers var det ingen patologiske forhold. CT abdomen/bekken (fig 1) viste noe ascites og prepylort var ventrikkelveggen sirkulært og diffust lett fortykket. Horisontale del av duodenum samt jejunum hadde noe uryddig slimhinnerelieff med fortykkede folder og fortykket tarmvegg som var litt uskarpt avgrenset mot fettvevet. Det var lett markerte lymfeknuter i jejunumkrøset. På overgangen til ileum ble tarmslyngene normalisert. Fecesprøver med tanke på patogene tarmbakterier, parasitter og kalprotektin var alle negative. Han var også Helicobacter pylori-negativ.

Ved oppfølgende enteroskopi fant man fortsatt noe ventrikkelretensjon. Slimhinnene $i$ antrum, duodenum og øvre del av jejunum var lett betente (fig 2), men forandringene var relativt beskjedne sett i lys av sykdomsbildet. Histologiske prøver av endoskopiske biopsier

\section{Hovedbudskap}

- Eosinofil gastroenteritt er en sjelden betennelsestilstand i mage-tarmkanalen

- Symptomene varierer og diagnosen kan være vanskelig å stille

- Annen årsak til eosinofil infiltrasjon i tarmvegg må utelukkes

- Tilstanden behandles med kortikosteroider 


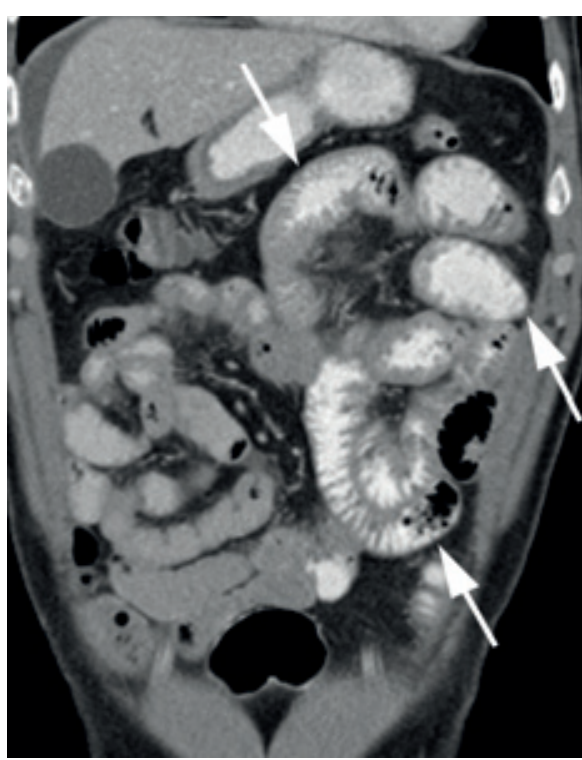

Figur 1 CT abdomen i koronal rekonstruksjon viser patologiske jejunumslynger med fortykket vegg og uregelmessige slimhinnefolder (piler)

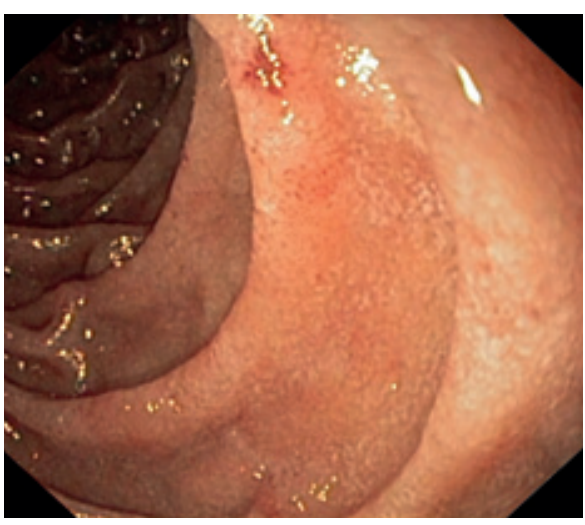

Figur 2 Endoskopibilde fra øvre del av tynntarm (jejunum) hvor slimhinnene fremtrer som lett betente

fra tynntarm (fig 3) viste infiltrasjon av eosinofile granulocytter med opp mot 50 celler per synsfelt, vesentlig i lamina propria, forenlig med eosinofil gastroenteritt.

Det ble startet behandling med peroral Prednisolon $40 \mathrm{mg} \times 1$,og symptomene bedret seg i løpet av få dager. Pasienten ble utskrevet med nedtrappende dose Prednisolon og videre poliklinisk oppfølging. Pasienten fikk symptomresidiv ved prednisolonreduksjon til 5 mg, og han bruker nå 7,5 mg som vedlikeholdsdose. Blodprøver tatt etter utskrivning på vedlikeholdsbehandling med prednisolon viste en forhøyet total IgE på 433 (normalt < 87), men ingen matvarespesifikke lgE-antistoffer.

\section{Eosinofile granulocytter i mage-tarm-kanalen}

Eosinofile granulocytter er multifunksjonelle, proinflammatoriske celler som utgjør en liten andel av sirkulerende leukocytter. De er involvert i ulike inflammatoriske tilstander, spesielt ved allergiske lidelser og parasittinfeksjoner, og har et bredt spektrum av funk- sjoner. Eosinofile granulocytter utvikles i beinmarg fra pluripotente stamceller og oppholder seg kort tid i sirkulasjonen før de går ut $\mathrm{i}$ vevene hvor de finnes $\mathrm{i}$ små mengder $\mathrm{i}$ mange organsystemer.

Mage-tarm-kanalen er, i tillegg til det hematopoetiske og lymfatiske system, hovedreservoar for eosinofile granulocytter hvor de utgjør en viktig del av infeksjonsforsvaret mot parasitter. Imidlertid har nok de eosinofile granulocyttene mer omfattende funksjoner enn bare forsvar mot parasitter, men dette er ikke fullstendig klarlagt. Migrasjon av eosinofile til lamina propria i mage-tarm-kanalen skjer allerede $\mathrm{i}$ fosterlivet, uavhengig av normalflora (2). Mengden eosinofile varierer i ulike avsnitt av mage-tarm-kanalen, men i oesophagus er de normalt ikke tilstede (3). Den høyeste konsentrasjonen finnes i appendix og proksimale del av colon, og det ser ut til at mengden her er avhengig av miljøfaktorer (4).

Det finnes en rekke tilstander som gir infiltrasjon av eosinofile granulocytter i magetarm-kanalen (5), ofte med ledsagende eosinofili i blod (ramme 1). Disse deles gjerne inn i idiopatiske/primære og sekundære (3), og symptomene spenner over et vidt spekter. Ved de primære tilstandene antar man at de eosinofile granulocyttene spiller en nøkkelrolle i patogenesen. Alle avsnitt av magetarm-kanalen kan rammes, og symptomene er avhengige av lokalisasjon og hvilke vegglag som hovedsakelig er affisert. Ved de primære tilstandene rammes bare mage-tarmkanalen, og man finner ikke tegn til sykdom $i$ andre organsystemer. Unntaket er hypereosinofilt syndrom som kjennetegnes av langvarig eosinofili i blod $\left(>1500 \cdot 10^{6} / 1\right.$ i minst seks måneder) samt symptomer og tegn på affeksjon av ulike organsystemer som hjertet, sentralnervesystemet, mage-tarm-kanalen, etc. Denne tilstanden omtales ikke videre i denne oversikten.

\section{Primær eosinofil gastroenteritt}

Eosinofil gastroenteritt kan ramme alle aldersgrupper, men forekommer hyppigst hos unge til middelaldrende voksne $(6,7)$. Det er en viss overvekt hos menn (7) og sykdommen affiserer oftest antrum ventriculi og proksimale tynntarm $(6,7)$. Også distale tynntarm og colon kan være involvert, men sannsynligvis er isolert eosinofil kolitt på samme måte som eosinofil øsofagitt, en egen entitet (8). Sykdomsdebut er svært varierende, fra akutt abdomen med kraftige magesmerter til mer snikende debut over uker og måneder. De vanligste symptomene er magesmerter og diaré. Symptomene er avhengig av hvilke vegglag som er affisert, og det er vanlig å dele sykdommen i tre grupper basert på hvilket vegglag som hovedsakelig er involvert (6). Affeksjon av mucosa er hyppigst (7) og kan føre til kvalme, diaré, magesmerter, blødning, malabsorpsjon og proteintap i tarmen. Obstruktive symptomer som måltidsrelaterte magesmer- ter og kvalme/brekninger ser man typisk ved affeksjon av muscularis, affeksjon av serosa kan gi ascites. Symptomene er også avhengig av hvilken del av mage-tarm-kanalen som er påvirket, og eksempelvis er magesmerter, kvalme og eventuelt oppkast i forbindelse med måltid vanlig når antrum ventriculi og proksimale tynntarm er involvert. Ved affeksjon i duodenum kan området rundt papilla Vateri involveres, og det er beskrevet flere tilfeller av pankreatitt assosiert med dette $(9,10)$, som hos vår pasient. Ett tilfelle av icterus er også rapportert (9).

Etiologi og patogenese av eosinofil gastroenteritt er ikke avklart. Det er økt risiko dersom et familiemedlem har tilstanden (11). I hvilken grad allergi eller allergisk disposisjon spiller en rolle for sykdommen er også uklart. Assosiasjon til allergi finnes hos ca. 50\% av pasientene i ulike studier $(6-8,12)$, men tallene varierer mye og studiepopulasjonene varierer. Det synes å være større assosiasjon til allergi hos unge individer (11), og det er også rapportert om synkron debut av bronkial astma og eosinofil gastroenteritt (13). Ingen av våre pasienter hadde kjent allergi. Hos en del pasienter finnes forhøyet total-IgE, og IgEmedierte prosesser kan være involvert, men dette kan ikke forklare hele sykdomsbildet. Det har vært forsøkt behandling med IgEantistoff, men med usikkert resultat (14).

\section{Diagnostikk}

De kliniske symptomene er ikke spesifikke og er avhengig av hvilken del av mage-tarmkanalen som er involvert. Antakelig er tilstanden underdiagnostisert da lette tilfeller kan ha vage symptomer, normale blodprøver og upåfallende funn ved endoskopi. At man er oppmerksom på sykdommen, er derfor avgjørende for diagnosen. Det er ikke uvanlig at det går lang tid fra symptomdebut til diagnose (15). Det er generelt akseptert at denne baserer seg på tilstedeværelse av symptomer fra fordøyelsessystemet, selektiv eosinofil infiltrasjon i mage-tarm-kanalen og fravær av andre årsaker til eosinofili.

Man har ingen spesifikke blodprøver ved eosinofil gastroenteritt, men man finner økt antall eosinofile granulocytter i blod hos omtrent tre firedeler av pasientene $(7,12)$, spesielt høye verdier kan ses ved affeksjon av serosa. Total-IgE angis å være forhøyet hos de fleste pasienter i en del oversiktsartikler (16), slik man ofte ser ved eosinofil øsofagitt, men det er vanskelig å finne robuste data for en slik påstand, og mange pasienter har normal total-IgE (17). Fecesanalyser med tanke på infeksjoner bør utføres, spesielt hos dem som har vært i risikoområder for parasittinfeksjoner.

De endoskopiske funnene er uspesifikke. Man kan finne erytem, ødem og fortykkede slimhinnefolder $(12,15)$. Forandringene er ofte sparsomme og korrelerer ikke nødvendigvis med de kliniske symptomene, og kan dermed være vanskelige å legge merke til. Det er heller ikke uvanlig at slimhinnene er ma- 
kroskopisk normale. Hos noen kan imidlertid forandringene være mer uttalte, med lettblødende slimhinner og ulcerasjoner $(15,18)$.

Histologisk finnes normalt eosinofile granulocytter i lamina propria i hele gastrointestinaltractus unntatt $i$ oesophagus, og det har derfor vært usikkerhet om hva som kan kalles en reell økning i antall. Det finnes ingen konsensus for de histologiske kriteriene for eosinofili i mage-tarm-kanalen, men man har foreslått minst 20 eosinofile granulocytter per synsfelt (400x forstørrelse) som grenseverdi (cut off) $(7,15)$. Dette vil imidlertid bare gjelde i ventrikkel og proksimale deler av tynntarmen da det normalt kan finnes høyere antall eosinofile granulocytter i distale ileum og proksimale colon (19). Andre faktorer som lokalisasjon av eosinofile granulocytter i tarmveggen og fravær av annen patologisk forandring (for eksempel vaskulitt) må vurderes. Man må også være oppmerksom på at forandringene kan være fokale, så det er viktig med flere biopsier ved endoskopi $(7,12,20)$. Vi tar minst fem biopsier fra antrum og fem fra duodenum ved gastroskopi når det er mistanke om eosinofil gastroenteritt (14). I tillegg utføres enteroskopi ved behov.

Det er uavklart hvor stor andel av pasientene med eosinofil gastroenteritt som har radiologiske forandringer. Tilstanden har ikke patognomoniske forandringer ved bildediagnostiske undersøkelser, funn er både uspesifikke og variable, men minner mer om inflammatorisk affeksjon enn neoplastisk sykdom. De vanligste funnene, vesentlig ved mukøs affeksjon, er fortykket tarmvegg og uregelmessig tarmrelieff med fortykkede irregulære folder. Ved affeksjon av dypere vegglag kan man se rigiditet, dysmotilitet og stenose. Ved subserosal affeksjon kan man finne ascites, ødema-

\section{Ramme 1}

Tilstander som kan gi infiltrasjon
av eosinofile granulocytter
i mage-tarm-kanalen
- Primær
Lokal
- Eosinofil øsofagitt
- Eosinofil gastroenteritt
- Eosinofil kolitt
Systemisk
- Hypereosinofilt syndrom
Sekundær
- Infeksjoner (parasitter)
- Inflammatorisk tarmsykdom
- Cøliaki
- Refluksøsofagitt
- Medikamenter
- Malign sykdom
- Vaskulitt (Churg-Straus' syndrom)
- Sklerodermi
- Transplantat-mot-vert

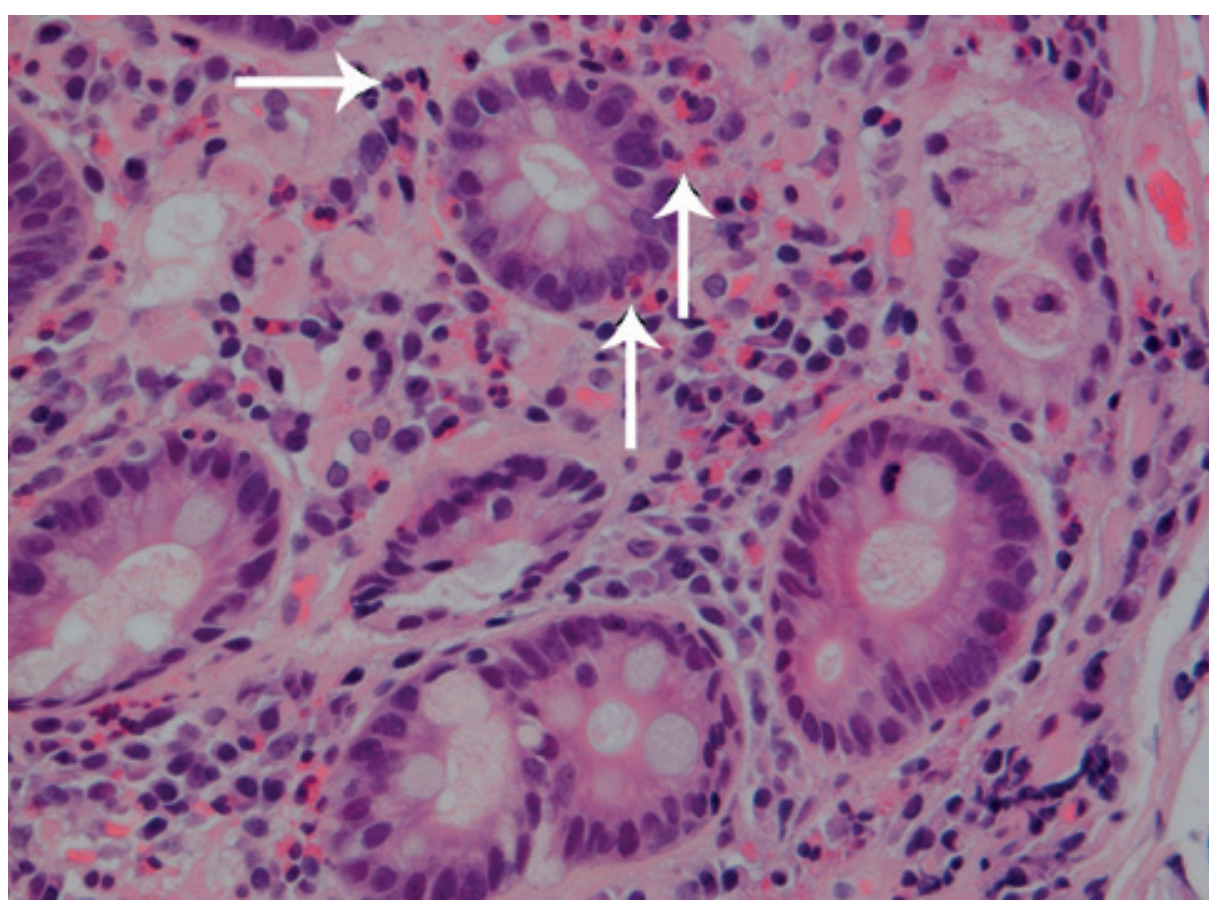

Figur 3 Histologisk snitt fra slimhinne i proksimale tynntarm viser økt antall eosinofile granulocytter (piler) i lamina propria og fokalt i relasjon til kjertelepitel

tøst fettvev, adheranser og forstørrede lymfeknuter $(21,22)$. Enkelte tilfeller av perforert tarm er også publisert (15).

Man kan finne uspesifikke forandringer ved en rekke bildediagnostiske undersøkelser som oversikt abdomen, ultralyd abdomen og tynntarmspassasje, men CT abdomen vil gi mest spesifikk diagnostisk informasjon. Etter vår erfaring gir $\mathrm{CT}$ utført med kontrastmarkert tarmlumen og intravenøs kontrast de beste muligheter for å oppdage tilstanden. Radiologisk er det mange differensialdiagnoser, men det er viktig å være oppmerksom på denne type uspesifikk tarmpatologisk tilstand og mulighet for eosinofil gastroenteritt.

\section{Behandling}

Det mangler gode studier om behandling av eosinofil gastroenteritt. Eventuelle utløsende faktorer bør fjernes, men slike påvises sjelden. Effekt av diett er dårlig dokumentert, men kostregulering kan være av nytte hos enkelte pasienter der man påviser spesifikk IgE eller vedkommende har positiv kutan prikktest mot matvarer. Generelt er det imidlertid dårlig korrelasjon mellom IgE/prikktest og symptomatologi (20). Eliminasjonsdiett er også forsøkt med varierende resultat. Slik behandling er lite praktisk i hverdagen og synes ikke å gi vedvarende effekt (20).

Den eneste behandlingen som synes å ha sikker effekt, er kortikosteroider i varierende dosering $(6,7,12,15)$. Man starter oftest med en høy dose prednisolon på 20-40 mg daglig og trapper denne langsomt ned over mange uker, lik den behandlingen man tradisjonelt har gitt pasienter med inflammatorisk tarmsykdom. Risikoen for tilbakefall er stor (12) og krever ofte nye behandlingsperioder.

Det er forsøkt en rekke andre medikamen- ter ved eosinofil gastroenteritt, som protonpumpehemmere, kromoglikat, antihistaminer, leukotrienantagonister, budesonid og IgE-antistoffer, men ingen kontrollerte studier er så langt foretatt. Symptomatisk behandling av diaré med somatostatinanalogen octreotid er også prøvd. Hos pasienter med symptomgivende stenoser eller perforasjon kan kirurgisk inngrep bli nødvendig $(7,15$, 17, 23). Eosinofil gastroenteritt er imidlertid en benign tilstand og langtidsprognosen synes god $(6,15)$, selv om dokumentasjonen også på dette feltet er begrenset.

\section{Konklusjon}

Eosinofil gastroenteritt er en sjelden og sannsynlig kronisk betennelsestilstand med ukjent etiologi. Den kliniske presentasjonen er svært variabel og tilstanden er antakelig underdiagnostisert. En del pasienter har normale eosinofile granulocytter i blod og normale funn ved endoskopi, korrekt diagnose er derfor avhengig av at man er oppmerksom på tilstanden. Det er også viktig at sekundære årsaker til eosinofili utelukkes. Det er mulig at de ulike eosinofile sykdommene i mage-tarm-kanalen er varianter av samme sykdom. Men da dette er sjeldne tilstander, har man foreløpig ikke kunnet avklare dette.

Oppgitte interessekonflikter: Ingen

\footnotetext{
Litteratur

Kaijser R. Zur Kenntnis der allergischen Affektionen des Verdauungskanal vom standpunkt des Chirurgen aus. Arch Klin Chir 1937: 188: 36-64 2. Mishra A, Hogan SP, Lee JJ et al. Fundamental signals that regulate eosinophil homing to the gastrointestinal tract. J Clin Invest 1999; 103: 1719-27.

3. Straumann A. Idiopathic eosinophilic gastrointestinal diseases in adults. Best Pract Res Clin Gastroenterol 2008; 22: 481-96.
} 
4. Pascal RR, Gramlich TL, Parker KM et al. Geographic variations in eosinophil concentration in normal colonic mucosa. Mod Pathol 1997; 10: 363-5.

5. Mueller S. Classification of eosinophilic gastrointestinal diseases. Best Pract Res Clin Gastroenterol 2008; 22: 425-40.

6. Klein NC, Hargrove RL, Sleisenger MH et al. Eosinophilic gastroenteritis. Medicine (Baltimore) 1970; 49: 299-319.

7. Talley NJ, Shorter RG, Phillips SF et al. Eosinophilic gastroenteritis: a clinicopathological study of patients with disease of the mucosa, muscle layer, and subserosal tissues. Gut 1990; 31: 54-8.

8. Rothenberg ME. Eosinophilic gastrointestinal disorders (EGID). J Allergy Clin Immunol 2004; 113 : 11-28, quiz 29.

9. Sheth A, Palmer R, Jordan PA et al. Eosinophilic gastroenteritis of the pancreas: an unusual cause of obstructive jaundice. J Clin Gastroenterol 2006; 40: 623-5

10. Lyngbaek S, Adamsen S, Aru A et al. Recurrent acute pancreatitis due to eosinophilic gastroenteritis. Case report and literature review. JOP 2006; 7: 211-7.

11. Guajardo JR, Plotnick LM, Fende JM et al. Eosinophil-associated gastrointestinal disorders: a world-wide-web based registry. J Pediatr 2002; 141: 576-81.

12. Chen MJ, Chu CH, Lin SC et al. Eosinophilic gastroenteritis: clinical experience with 15 patients. World J Gastroenterol 2003; 9: 2813-6.

13. von Wattenwyl F, Zimmermann A, Netzer P. Synchronous first manifestation of an idiopathic eosinophilic gastroenteritis and bronchial asthma. Eur J Gastroenterol Hepatol 2001; 13: 721-5.

14. Foroughi S, Foster B, Kim N et al. Anti-IgE treatment of eosinophil-associated gastrointestinal disorders. J Allergy Clin Immunol 2007; 120 594-601.

15. Lee CM, Changchien CS, Chen PC et al. Eosinophilic gastroenteritis: 10 years experience. Am J Gastroenterol 1993; 88: 70-4.

16. Conus S, Simon HU. General laboratory diagnostics of eosinophilic GI diseases. Best Pract Res Clin Gastroenterol 2008; 22: 441-53.

17. Caldwell JH, Mekhjian HS, Hurtubise PE et al. Eosinophilic gastroenteritis with obstruction. Immunological studies of seven patients. Gastroenterology 1978; 74: 825-8

18. Scolapio JS, DeVault K, Wolfe JT. Eosinophilic gastroenteritis presenting as a giant gastric ulcer. Am J Gastroenterol 1996; 91: 804-5.

19. Lowichik A, Weinberg AG. A quantitative evaluation of mucosal eosinophils in the pediatric gastrointestinal tract. Mod Pathol 1996; 9: 110-4.

20. Leinbach GE, Rubin CE. Eosinophilic gastroenteritis: a simple reaction to food allergens? Gastroenterology 1970; 59: 874-89.

21. Vitellas KM, Bennett WF, Bova JG et al. Radiographic manifestations of eosinophilic gastroenteritis. Abdom Imaging 1995; 20: 406-13.

22. Zheng $X$, Cheng J, Pan K et al. Eosinophilic enteritis: CT features. Abdom Imaging 2008; 33: 191-5.

23. Yun MY, Cho YU, Park IS et al. Eosinophilic gastroenteritis presenting as small bowel obstruction: a case report and review of the literature. World J Gastroenterol 2007; 13: 1758-60.

Manuskriptet ble mottatt 21.5. 2010 og godkjent 16.9. 2010. Medisinsk redaktør Michael Bretthauer. 